\title{
Characterization of Antimicrobial Peptides from Local Forest Dwelling Ants: In-vitro Screening for Antimicrobial Activity
}

\author{
Barna Chakraborty, Debashis Gayen, and C. Deeya Ghosh Dastidar
}

\section{ABSTRACT}

\begin{abstract}
Antimicrobial peptides (AMPs) recognized as host defense peptide (HDPs), have achieved considerable attention during last two decades as potential components of the instinctive immune system. Amongst the insects over casted for AMPS the hymenopterans comprising of ants have been identified for possessing potent antimicrobial peptides, those are small linear peptides. An investigation was taken up to screen for antimicrobial peptides collected from ants thriving in Forest Plantation in Hijli of Midnapore District, W.B. Three species of ants, members of the family Formicidae, were collected for in vitro antimicrobial activities of the whole body extract. These were tested by in the $10 \%$ of acetic acid solution using the Kirby-Bauer disc diffusion method against test microorganism viz. Escherichia coli, Staphylococcus mutans, Vibrio cholarae and Candida albicans. A strong antimicrobial activity was noted in all the extracts against all the microorganisms. The Spectrophotometric scanning was carried out to confirm the presence of peptides. TLC and HPLC were done. The result revealed that all the three species of ants exploited in this study were found to be a promising source of antimicrobial peptides.
\end{abstract}

Keywords: Antimicrobial peptides, Escherichia coli, Formicidae, HPLC, TLC.

\section{INTRODUCTION}

Majority of living organisms are susceptible to harmful pathogen ingestion and inhalation which are indeed potential. The endurance of such organisms in a microbe thriving environment depends on a network of host defence system involving a variety of components. Pathogens that penetrate immediately the first line of defence involves the innate immune responses which in turn are followed by acquired immune response involving the activation of $\mathrm{T}$ and $\mathrm{B}$ cells expression against particular antigens. In the perspective of a distinct approach these acquired immune mechanisms, endogenous peptides, [1] which are constitutively appeared or induced (in a few cases), provides a fast and useful means of defence against the pathogen. Those molecules identified as Antimicrobial Peptides (AMPs) which constitutes primitive immune defence mechanisms and is found in the extensive range of eukaryotic organisms, from human to plants and again to insects. Most of these peptides encoded by genes are mobilized shortly after microbial infections and act rapidly to neutralize a wide range of microbes and usually share several common properties. For instance, most of these abundant groups of antimicrobial peptides are less than $10 \mathrm{KDa}$, however the overall structure is similar having a net positive charge, hydrophobicity and are membrane active. It is now evident that antimicrobial peptides are primary elements of the innate immunity against microorganisms specially bacteria and fungi in both the animal and the plant kingdom [2]-[4]. Of the remarkable number of known antimicrobial structures at least $50 \%$ were identified in invertebrates and major portion within insects. In 1981, Boman and colleagues isolated and fully characterized the inducible antibacterial peptide from the diapausing pupae of the giant silk moth, Hylaphora cecropia [5] Insect cecropins are highly effective against Gram-positive bacteria [6] since the original report of cecropin from Boman, claimed the accessibility of more than 170 antimicrobial peptides/polypeptides in insects. They shared few common features like relatively low molecular weight (below $5 \mathrm{kDa}$ ), and are positively charged at physiological $\mathrm{pH}$, while for most of them, amphiphilic a-helices or hairpin-like b-sheetsor mixed structures. In the perspective structural features, these peptides can be broadly classified into three categories (i) linear peptides constituting a-helices and devoid of cysteine residues; (ii) cyclic peptides containing cysteine residues and (iii) peptides with an overrepresentation in proline and/or glycine residues.

\section{MATERIALS AND METHOD}

\section{A. Ant Samples Collection}

The worker ants of family Formicidae were collected using a brush and forceps from their natural habitat during day time within $2 \mathrm{KM}$ of Hijli Forest range, of Midnapore Dist, W.B during the year of 2018. Prior to collection a small bud of cotton soaked in ether is inserted in the flask. The collected ants were isolated from nest debris and soil particles and after inactivating them those were transferred to $15 \mathrm{ml}$ falcon tubes \& stored at - 
$80{ }^{\circ} \mathrm{C}$ freezer. The frozen ants were sieved again in $1.7 \mathrm{~mm}$ sieve for separating the darts.

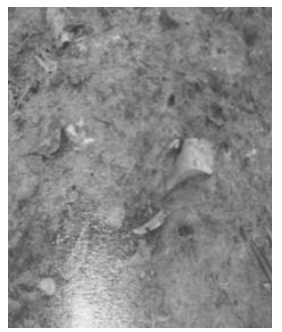

Fig. 1. Habitat of sample A.

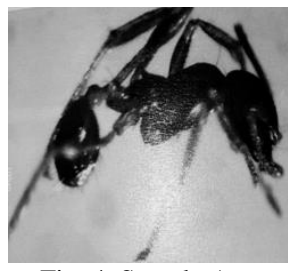

Fig. 4. Sample A.

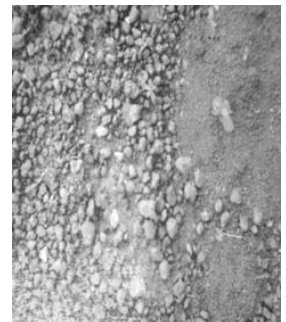

Fig. 2. Habitat of sample B.

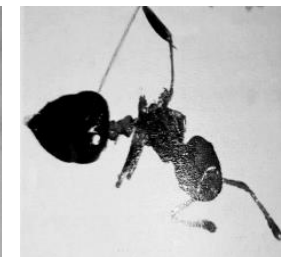

Fig. 5. Sample B.

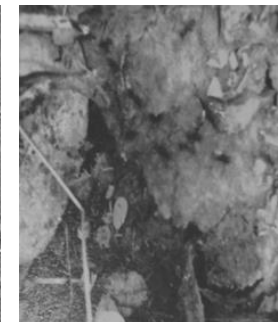

Fig. 3. Habitat of sample C.

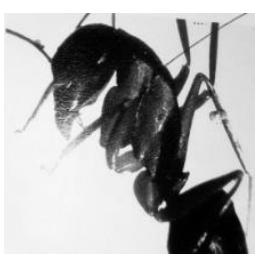

Fig. 6. Sample C.

\section{B. Identification of Ant Sample}

The samples were identified up to the genus and species level in Zoology Laboratory, DDE, Vidyasagar University, Midnapore (W.B) by using binocular microscope and based on the literature available [7]-[11]. Species name, authority and spelling had been followed to Catalogue of Ants of the world for the Formicidae [12]. So, finally the samples were identified as Sample A - Solenopsis geminata, Sample B Solenopsis invicta, and Sample C-Camponotus compressus.

\section{Extraction and Purification of Peptides from the Supernatant of Whole Body Extract of Ant}

Whole body extract of ant [13] is done to purify the total peptides present in the ant body. These total peptides will be used to investigate the presence of anti-microbial peptides. $10 \%$ acetic acid is prepared (Glacial acetic acid \& ultrapure water at 1:9 ratios) and chilled at too. Motor pastel is precooled at $-80^{\circ} \mathrm{C}$ freezer. The stored samples were taken out from the $-80{ }^{\circ} \mathrm{C}$ freezer and $2 \mathrm{~g}$ of the sample is taken in chilled motor pastel. Liquid Nitrogen is added and immediately crushed to powder. The crushed powdered extract is collected in $50 \mathrm{ml}$ Falcon tube. The powdered extract is suspended in $25 \mathrm{ml}$ of pre-cooled $10 \%$ acetic acid solution and vortex vigorously. The homogenate extract is collected in $16 \mathrm{ml}$ centrifuge tube and centrifuged in Sorvall $\mathrm{RC} 6+$ centrifuge (SS34 fixed rotor) at 7000RPM $\left(4^{\circ} \mathrm{C}\right)$ for $25 \mathrm{~min}$, the supernatant is now collected, and others are disposable. The supernatant of the extract is filtered by Whattman 41 filter paper to remove leftover debris after centrifugation. Then the filtrate was filtered in sterile filtration apparatus $(0.22 \mu \mathrm{m}$ filter membrane $)$ by applying vacuum. The filtrate of the $0.22 \mu \mathrm{m}$ filter membrane is taken upper chamber of the Millipore Amicon ultra filter $(10 \mathrm{KD}$ cut up) and centrifuged at $3500 \mathrm{RPM}\left(4{ }^{\circ} \mathrm{C}\right)$ for $10 \mathrm{~min}$. The purified protein is collected in a fresh falcon tube and kept in $4{ }^{\circ} \mathrm{C}$ freezer.

\section{Spectrophotometric Analysis of Purified Peptides}

Spectrometric scanning [14] was done at wavelength from $200 \mathrm{~nm}$ to $800 \mathrm{~nm}$ in Varian Cary 50 split beam spectrophotometer, to screen the presence of peptides in the purified sample. Absorbance vs wavelength has been plotted with the help of the instrument software.

\section{E. Determination of Concentration of Peptide Sample by Bradford Method}

The basic reagents are Bovine Serum Albumin (BSA), Coomassine Brilliant Blue G-250 as dye, Bradford reagent, along with spectrophotometer and Whatman no. 1 filter paper [15]. The maximum absorbance at $470 \mathrm{~nm}$ when the dye turned into red, when it changes in anionic blue then the absorbance is $595 \mathrm{~nm}$, and when it comes in neutral green the absorption is $650 \mathrm{~nm}$. [16] Two standard solutions of 100 $\mu \mathrm{g} / \mathrm{ml}$ and $200 \mu \mathrm{g} / \mathrm{ml}$, standard protein is prepared using dilution $1 \mathrm{mg} / \mathrm{ml}$ BSA solution. $20 \mu \mathrm{l}$ standard solution with sample has taken into 5 micro centrifuge tubes. $100 \mu \mathrm{l}$ of Bradford reagent is used to each of the protein solution and leftover for 10 mins. Reading was taken in Nanodrop spectrophotometer at $595 \mathrm{~nm}$ as per software protocol.

\section{F. Concentrating of the Peptide Samples for Purification and Analysis}

The sample is concentrated by freeze drying at $-50{ }^{\circ} \mathrm{C}$ in Eyela FDU 1200 Freeze dryer for further analysis for antimicrobial activity, HPLC purification, TLC of the sample.

\section{G. Kirby-Bauer Disc Diffusion Sensitivity Test}

The disc diffusion method is more suitable for testing isolates are testing for susceptibility to numerous antimicrobial agents. A Mueller Hinton agar plate is equally inoculated with the sample organism and a paper disc had been saturated with a suttled concentration of antimicrobial agent fixed on the surface of the agar [17]. Diffusion of the antimicrobial agent and the growth of organisms were placed in a circular zone of inhibition through which the antimicrobial agent overruns inhibitory concentration. By using of sterile cotton swab in the previously cultured bacterial sample removed the excess fluid. To obtain uniform growth, the swab streaked at least 3 directions over the Mueller Hinton agar. The plate left for 5 mins to dry out. After that Sample A, B, C were placed by a sterile force for 15 mins. The plates were incubated soon after placing the disc when the diffusion of AMPs and the growth of bacteria initiate at the same time. Need the overnight incubation, the diameter of the zone of growth of the inhibition were measured around each disc. Plates were examined carefully at the zone of inhibition. Disc diffusion method is again repeated after HPLC purification of the peptides, vacuum dried \& re-suspended the sample in Phosphate Buffer saline $\mathrm{pH} 7.4$.

\section{H. Bacterial Sample Used Preparation for Testing Kirby- Bauer Disc Diffusion Sensitivity Test}

Vibrio cholerae, Escherichia coli, Candida albicans and Streptococcus mutans have been used. Freeze dried bacterial culture were taken out from each vial inside bio-safety cabinet and included in a culture tube containing sterilized Luria Broth medium with inoculation loop. The culture tubes are incubated at $37{ }^{\circ} \mathrm{C}$ for $20 \mathrm{~h}$ till optimum growth of bacteria observed. For sub-culturing $50 \mu \mathrm{l}$ of the confluent cell were inoculated in $10 \mathrm{ml}$ of culture media in conical flax containing sterile Luria Broth medium. The flax was again 
incubated at $37^{\circ} \mathrm{C}$ till the cells become confluent. The culture has been taken out of the incubator and stored at $4{ }^{\circ} \mathrm{C}$.

\section{Separation of the Peptide Samples by TLC}

The freeze dried sample is re-suspended in 20\% CAN (Acetonytrile: Water, at 20:80). Mobile phase was prepared by mixing of acetone : butanol : water, at 60:20:20. The TLC plate was dried, Ninhydrin solution sprayed and the plate is heated on hot plate. Ninhydrin (2,2- Dihdroxyindane-1,3dione) reacts with the free amine [18] of the separated peptides and produced Ruhemann's purple colour.

\section{J. Separation of the Peptide Samples by HPLC}

The freeze dried sample is re-suspended in $1 \mathrm{ml}$ of 20 aquas acetonitrile and purified in Agiland 1100 gradient HPLC system with Diode Array Detector and Zorobax SB C18, $5 \mu \mathrm{m}, 4.6 \mathrm{X}, 250 \mathrm{~nm}$ reverse phase column was used for separating the sample [19]. The column was previously equilibrated with acetonitrile $50 \%(\mathrm{CH} 3 \mathrm{CN})$ and ultrapure water (Sartorius). $50 \mu \mathrm{l}$ of the re-suspended sample was injected and eluted stepwise with $10 \%, 20 \%, 30 \%, 40 \%$, \& $60 \% \mathrm{CH} 3 \mathrm{CN}$ gradient in $0.1 \% \mathrm{TFA} /$ water. The eluting was detected in diode array detector at $210 \mathrm{~nm}$ and $280 \mathrm{~nm}$ wavelength. The eluted samples having absorbance at $210 \mathrm{~nm}$ were collected in Fraction Collector (Pharmacia). The separated peptides were dried in speed vac concentrator (EYELA) and tested for antimicrobial activity as per KirbyBauer's Disc Diffusion sensitivity test (W. Kirby \& A. Bauer 1950s).

\section{RESULT}

\section{A. Analysis of Peptides in Spectrophotometer}

Spectrometric scanning was performed peptides obtained from Sample A has absorbance at $239.910 \mathrm{~nm} \& 255.43 \mathrm{~nm}$, for Sample B $239.910 \mathrm{~nm}$, and for Sample C $206.52 \mathrm{~nm}$ \& $219.94 \mathrm{~nm}$.

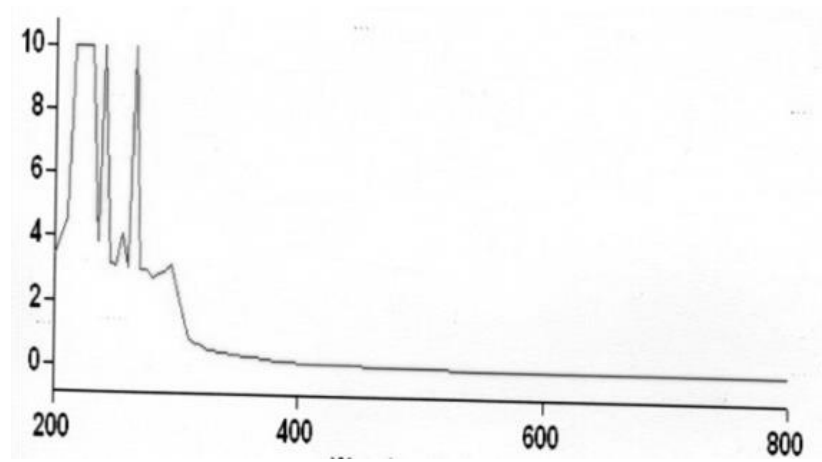

Fig. 7. Spectrometric scanning of Sample A.

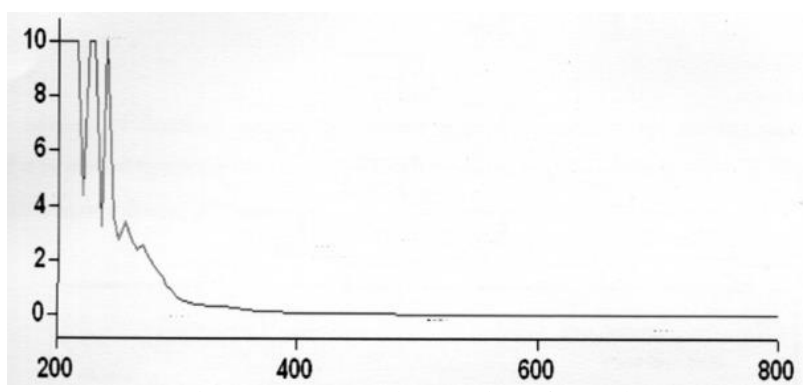

Fig. 8. Spectrometric scanning of Sample B.

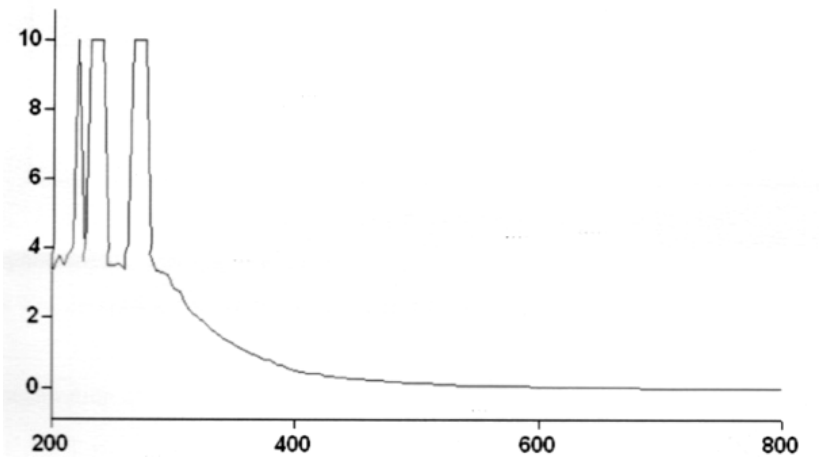

Fig. 9. Spectrometric scanning of Sample $\mathrm{C}$ where $\mathrm{X}$ - axis indicates Abs and Y-axis indicates Wavelength (nm).

\section{B. Bradford Assay of Peptides}

After addition to Bradford reagent samples were incubated for 5 mins \& standard curve was plotted by taking the average of 5 successive reading $(595 \mathrm{~nm})$ of standard as per instrument software protocol.

Spectrophotometric reading was taken for each of the sample and the sample concentration was examined from the standard curve with the help of software of the instrument. The concentrations of the unknown peptide samples are follows: 1. Sample A- $163 \mu \mathrm{g} / \mathrm{ml}, 2$. Sample B-169.9 $\mu \mathrm{g} / \mathrm{ml}$, 3. Sample C- $141.3 \mu \mathrm{g} / \mathrm{ml}$.

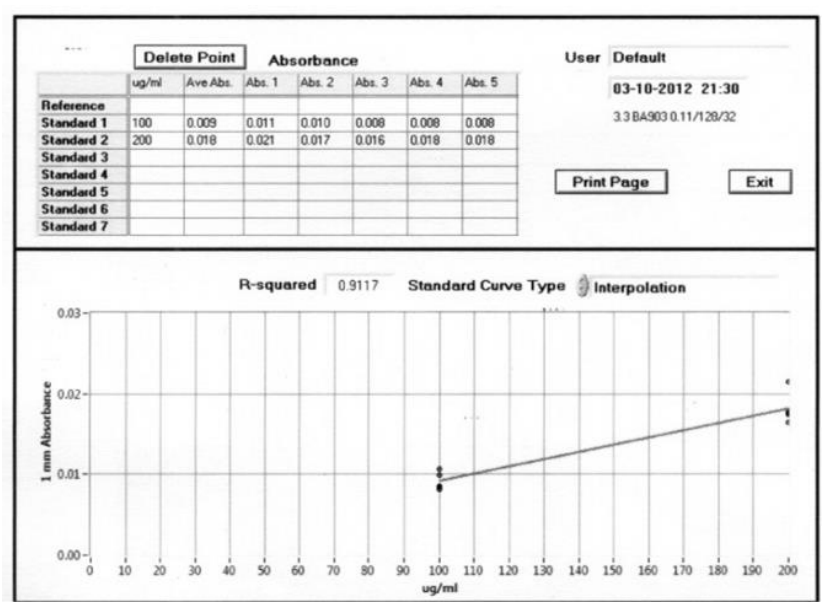

Fig. 10. Standard curve of BSA standards of Bradford test.

\section{Kirby-Bauer Disc Diffusion Sensitivity Test against Bacteria}

The purified crude sample is used for testing present of any antimicrobial activity. After incubation for $18 \mathrm{~h}$ the culture plates were examined, all the peptide samples antimicrobial activity against Vibrio cholerae, Escherichia coli, Candida albicans, Streptococcus mutans.

TABLE 1: DIAMETER OF ZONE OF MiCROBIAL GROWTH INHIBITION IS DisC DIFFUSION TEST (10KD PURIFIED SAMPLE)

\begin{tabular}{cccc}
\multicolumn{4}{c}{ DIFFUSION TEST (10KD PURIFIED SAMPLE) } \\
\hline Strains & Sample A & Sample B & Sample C \\
\hline Escherichia coli & $12 \mathrm{~mm}$ & $12 \mathrm{~mm}$ & $16 \mathrm{~mm}$ \\
Vibrio cholerae & $11 \mathrm{~mm}$ & Nil & $15 \mathrm{~mm}$ \\
Candida albicans & $14 \mathrm{~mm}$ & $11 \mathrm{~mm}$ & $17 \mathrm{~mm}$ \\
$\begin{array}{c}\text { Streptococcus } \\
\text { mutans }\end{array}$ & $16 \mathrm{~mm}$ & $12.5 \mathrm{~mm}$ & $18 \mathrm{~mm}$ \\
\hline
\end{tabular}




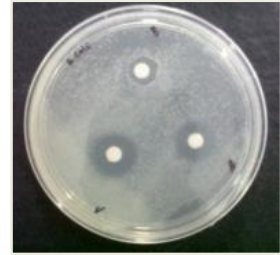

Fig. 11. Plate of E. coli.

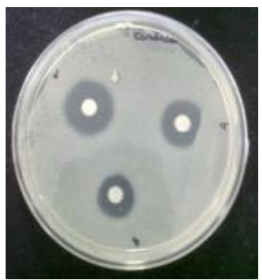

Fig. 13. Plate of C. albicans.
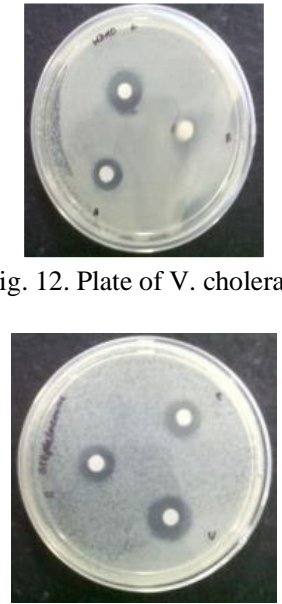

Fig.14. Plate of S. mutans
Fig. 12. Plate of V. cholerae.

\section{TLC of Purified Peptides}

The other part of the sample after freeze drying resuspended $20 \%$ ACN \& TLC was done. In TLC separation 3 bands were visualized after staining by Ninhydrin [20] for Sample A, 2 from Sample B, and 3 from Sample C. The Lane profiles were re-confirmed by scanning the TLC plate in densitometry scanner.

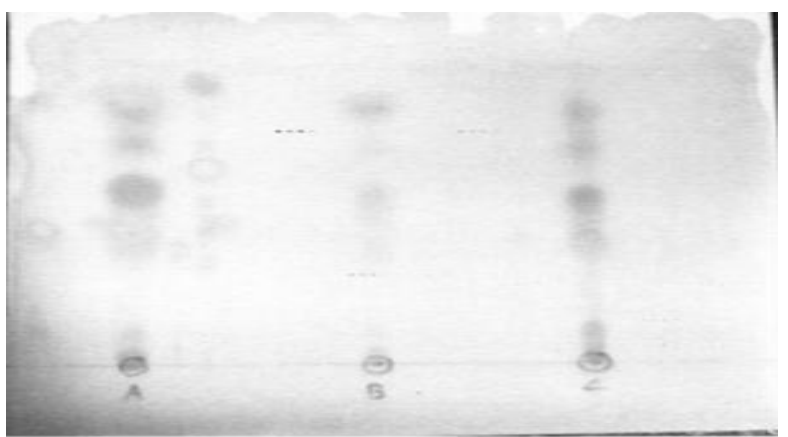

Fig. 15. Developed TLC plate (Ninhydrin).

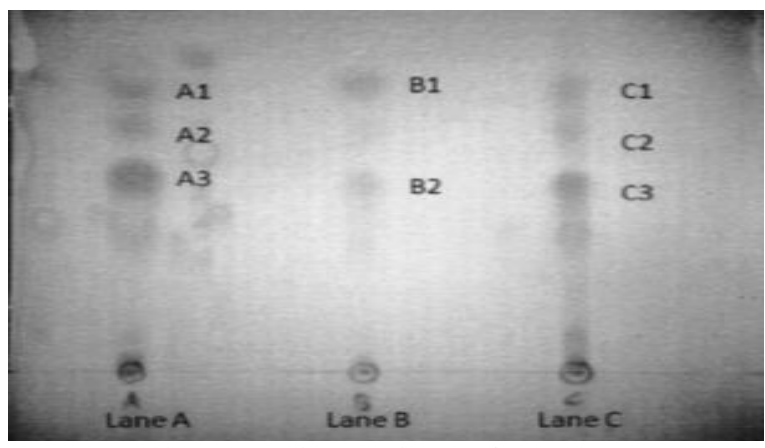

Fig. 16. Densitometer image of TLC plate.

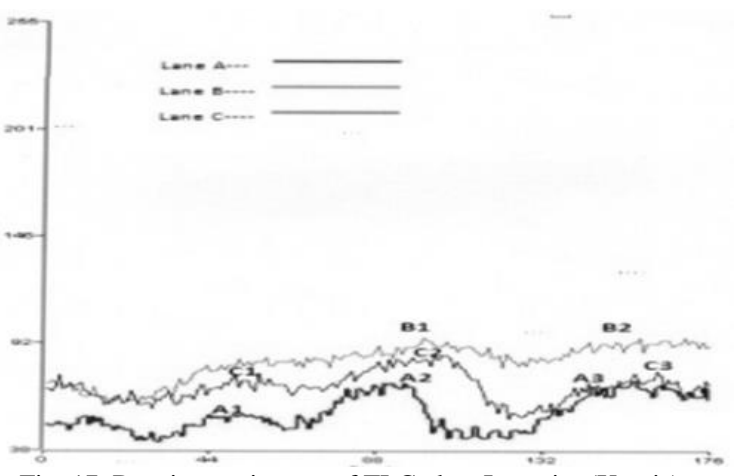

Fig. 17. Densitometric scan of TLC plate Intensity (X-axis) vs Prixel (Y-axis).

\section{E. HPLC Separation of Peptides}

Separated peptides in HPLC were detected at $210 \mathrm{~nm}$ and peptides were collected at 1.9 min for peptides of Sample A, at 3.9 min for peptides of Sample B, at 3.8 min for peptides of Sample C.

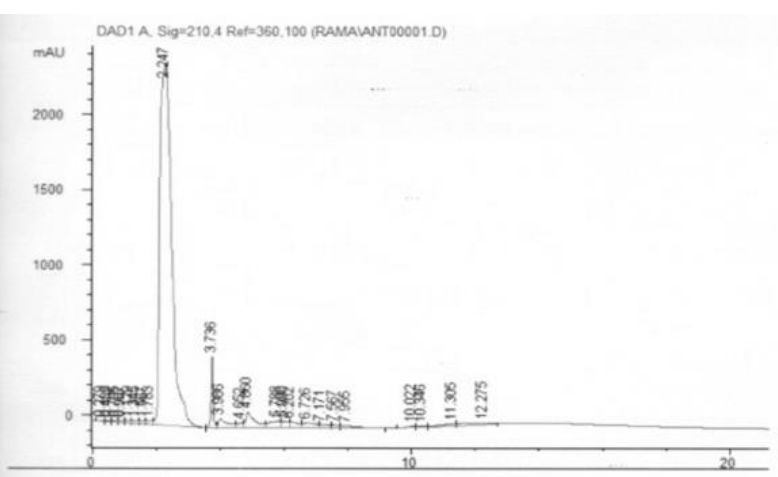

Fig. 18. DAD plot of HPLC separated peptides from sample A.

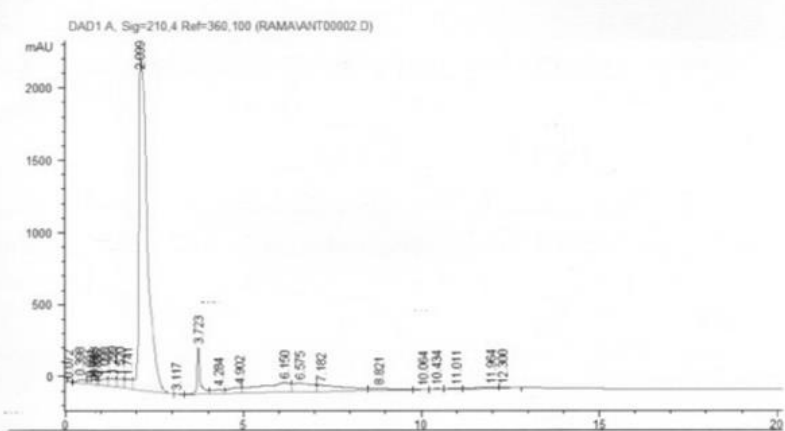

Fig. 19. DAD plot of HPLC separated peptides obtained from sample B.

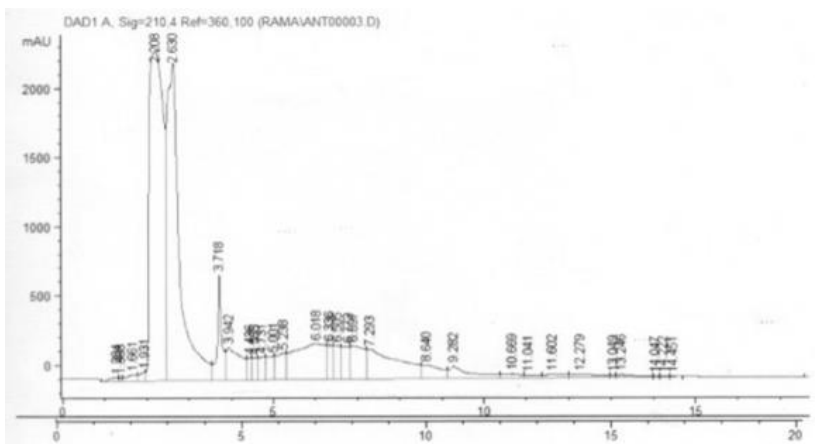

Fig. 20. DAD plot of HPLC separated peptides obtained from sample C.

F. Kirby-Bauer Disc Diffusion Sensitivity Test against Bacteria with the HPLC Purified Sample

After incubation for $18 \mathrm{hrs}$ the culture plates were examined, all the peptide samples have antimicrobial activity of the HPLC purified sample against Escherichia coli, Candida albicans, Vibrio cholera, Streptococcus mutans.

TABLE 2: DIAMETER OF ZONE OF MICROBIAL GROWTH INHIBITION IS DISC DIFFUSION TEST (HPLC PURIFIED SAMPLE)

\begin{tabular}{cccc}
\hline Strains & Sample A & Sample B & Sample C \\
\hline Escherichia coli & $30 \mathrm{~mm}$ & $30 \mathrm{~mm}$ & $25 \mathrm{~mm}$ \\
Vibrio cholerae & $12 \mathrm{~mm}$ & $30 \mathrm{~mm}$ & $25 \mathrm{~mm}$ \\
$\begin{array}{c}\text { Candida albicans } \\
\text { Streptococcus } \\
\text { mutans }\end{array}$ & $18 \mathrm{~mm}$ & nil & nil \\
\hline
\end{tabular}




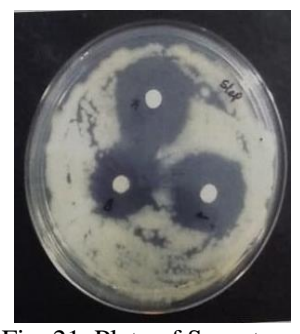

Fig. 21. Plate of S. mutans.

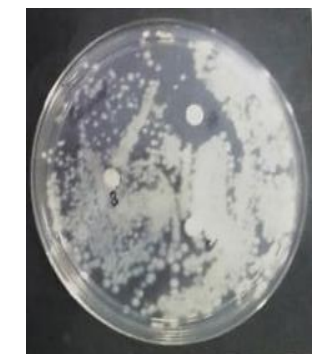

Fig. 23. Plate of C. albicans

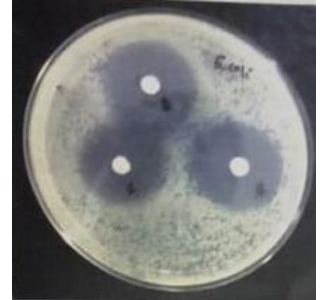

Fig. 22. Plate of E. coli.

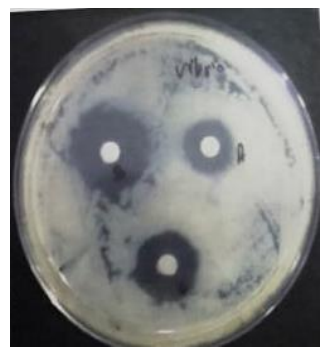

Fig. 24. Plate of V. cholerae, treated with HPLC fraction.

\section{DISCUSSION}

\section{A. Spectrophotometric Scanning of Purified Peptides}

Though peptides having their max absorbance at $210 \mathrm{~nm}$ [14] but there is a slight shift of absorbance between $206.52 \mathrm{~nm}$ to $239.910 \mathrm{~nm}$ due to presence of more than one peptides in $10 \mathrm{KD}$ cutup sample.

\section{B. Bradford Assay}

Coomassine Brilliant Blue binds with the arginine residue of the all the peptides and gave max absorbance at $595 \mathrm{~nm}$.

\section{Kirby-Bauer Disc Diffusion Sensitivity Test for Antimicrobial Peptides}

In this test, the growth of Escherichia coli, Candida albicans, Streptococcus mutans are inhibited by peptides obtained from sample A, B, C. The growth of Vibrio cholerae is resisted by peptides of sample A \& C only. The growth of the above mentioned bacterial strains are resisted due to presence of AMPs in the purified samples. As the samples were freeze dried before the test to remove residual amino acid used for extraction, so there are no chances of bacterial growth inhibition by amino acid. Streptococcus mutans is very sensitive to the AMPs of sample A, B, C. Vibrio cholerae is moderately sensitive to AMPs of sample A, strongly sensitive to sample $\mathrm{C}$ and not sensitive to sample $\mathrm{B}$. Escherichia coli is very sensitive to the AMPs of sample A \& C. And moderately sensitive to AMPs of sample B. Candida albicans is very sensitive to the AMPs of sample A, B, C. The purified fraction of HPLC shows strong antimicrobial activity against Escherichia coli and Streptococcus mutans. In Candida albicans peptide obtained from HPLC purification of sample has slightly inhibited in the growth at all. In Vibrio cholera peptides of sample A has very little effect of inhibition and peptides of sample B \& C has slightly inhibited the growth.

\section{TLC of Sample}

As there is a shift of spectrophotometric absorbance from $210 \mathrm{~nm}$, TLC was done to check to different peptides in the samples. Developed TLC plates have clearly shown separated distinct peptide bands. Peptides obtained from sample A

contains mixture of 3 peptides, A1, A2, A3. Peptides obtained from the sample B contain mixture of 2 peptides, B1, B2. Peptides obtained from sample $\mathrm{C}$ contain mixture of 3 peptides, $\mathrm{C} 1, \mathrm{C} 2$, and $\mathrm{C} 3$. The bands were reconfirmed by densitometry scanning and it also gave 3 peaks for peptides of sample A, 2 peaks for sample B, and 3 for sample C.

\section{E. HPLC Purification of the Peptides}

The samples were further separated in HPLC and detected in $210 \mathrm{~nm}$ by changing the polarity of peptides by applying a gradient of acetonytrile. Though the graph profile of sample A is shows 3 peptides in which 1 only separated in optimum quantity for further study. Only 1 peptide of sample B and more than 3 peptides show in sample $C$ in which 1 only separated optimally.

\section{CONCLUSION}

Ants are well known for potential sources of antimicrobial peptides, so far, several antimicrobial peptides are isolated from several genera of ants. By purifying and chemical characterizing of these peptides from these ants, many unknown peptides are received which have antimicrobial activity on pathogenic microbes. By Kirby-Bauer's disc diffusion sensitivity test it is clearly stated that the sensitivity of bacteria to the ant's AMPs. Streptococcus mutans noted very strongly sensitive to all of three testing AMPs. The purified fraction of HPLC shows strong antimicrobial activity against Escherichia coli and Streptococcus mutans. These peptides can be artificially synthesized and can be used as therapeutic drugs. In recent years, AMPs attracted global attention as potential outbreak for therapeutic applications in animal and human health and agriculture. This had led to a flurry of research on insects to identify candidate AMPs in further process. Hence, the future prospect would be to identify more of such novel antimicrobial peptides and develop novel recombinant protocols to obtain greater yield of peptides at a lower cost.

\section{ACKNOWLEDGEMENT}

The authors are grateful to Dr Ramapati Samanta, Technical Officer and other laboratory staff of IIT, Kharagpur for providing their excellent support in laboratory work. Preliminary work of Ants collection and identification were done in DDE, Zoology Lab of Vidyasagar University with full support of Vidyasagar University is also thankfully acknowledged.

\section{REFERENCE}

[1] Reddy KVR, Yedery RD and Aranha C 2004 Antimicrobial peptides: premises and promises, International journal of antimicrobial agents 24 (6), 536-547.

[2] Boman H. Peptide antibiotics and their role in innate immunity. Annual Review in Immunology 1995;13:61 \pm 92 .

[3] Ganz T, Weiss J. Antimicrobial peptides of phagocytes and epithelia. Seminar in Hematology 1997;34:343 \pm 54

[4] Broekaert WF, Terras FRG, Cammue BPA, Osborn RW. Plant defensins: novel antimicrobial peptides ascomponents of the host defense system. Plant Physiology1995;108:1353 \pm 8 .

[5] Steiner, H., D. Hultmark, A. Engstrom, H. Bennich, and H. G. Boman. 1981. Sequence and specificity of two antibacterial proteins involved in insect immunity. Nature292:246-248. 
[6] Hetru, C.; Troxler, L.; Hoffmann, J.A. Drosophiola melanogaster antimicrobial defense. June 2003, PagesS327-S334.

[7] Mathew R, Tiwari RN. Insecta: Hymenoptera: Formicidae. State Fauna Series 4, Zoological Survey of India Fauna of Meghalaya, 2000; 7:251409.

[8] Bolton B. Identification Guide to the Ant Genera of World. Cambridge: Harvard University Press. 1994, 232.

[9] Bingham CT. Fauna of British India, Vol. II. Taylor Francis, London. 1903, 106.

[10] Holldobler B, Wilson EO. The Ants. Springer-Verlag. 1990, 732.

[11] Hölldober B, Wilson EO. The ants. Cambridge, Massachusetts: Harvard University Press. 1990, 746.

[12] LAENEN BATR, Ursula Wiehart. Nadine De Decker, An antidiuretic factor in the forest ant, purification and physiological effects on the Malpighian tubules, 2003. 28, 305-314.

[13] Robert K Scopes, Measurement of spectrophotometry at 205nm, Analytical Biochemistry,1993, 59, 277-252(1974).

[14] Tsaffrir Zor, Zvi Selinger Linearization of the Bradford Assay, increases its sensitivity. Theoretical and experimental study. Analitical Biochemistry, 236. 302-308(1996).

[15] A Rapid and Sensitive Method for the Quantitation of Microgram Quantities of Protein Utilizing the Principle of Protein-Dye Binding, Marion M. Bradford, Reproduction Research Laboratories, Department of Biochemistry, University of Georgia, Athens, Georgia 30602, Analytical Biochemistry 72, 248-254(1976).

[16] Dr. M.K. Lalitha, Manual on Antimicrobial Suceptibility Testing. Tamil Nadu, 2004.

[17] Victor John Harding \& Francis H.S. Warnefrod, 1916.

[18] Robert K Scopes, ptotein purification, principle and practice, 1993, $3^{\text {rd }}$ edition.

[19] Carey B. Bottom, Mechanism of Ninhydrin reaction, 1995.

[20] Wieprecht T, Dathe M, Beyermann M, et al. Peptide hydrophobicity controls the activity and selectivity of magainin 2 amide in interaction with membranes. Biochemisrty 1997;36:6124-32. 